\title{
A Survey of English Language Teaching in Higher Institutions of Learning in Kuala Lumpur Malaysia
}

\author{
Tatiana Shulgina ${ }^{a *}$ and Gopal Sagaran ${ }^{b *}$ \\ * Tatiana Shulgina, ${ }^{a}$ Puchong, Selangor 47100, Malaysia \\ * Gopal Sagaran ${ }^{b}$ Puchong, Selangor 47100, Malaysia \\ ${ }^{a}$ Binary University, Malaysia; tatianaofficial1@gmail.com \\ binaryUniversity, Malaysia; gssagaran@hotmail.com
}

\begin{abstract}
The aim of this study is to explore the extent of English language teaching in Higher Institutions of Malaysia and investigate the current changes, trends and challenges in this niche. A sample of 100 English learners from public and private institutions participated in this study. Analysis of the responses indicated that English language is remaining to be difficult to master, due to speaking environment, proficiency of the teachers and other factors. However, the Government is on the right direction to improve this situation by following Common European Framework of Reference of Languages. As any other system, it takes time to put into realization and start up the mechanism. This observation carries a pedagogical perspective and includes the overview of the general picture based on Private, Public and Stand Alone English educational institutions. This study has highlighted the practical importance of British Framework of English learning and suggests to focus on emphasis of the learning process instead of a result.
\end{abstract}

Keywords: English language; motivational intensity; survey; trends; challenges in Malaysia 


\section{INTRODUCTION}

With the process of globalization, English language has become a dominant international language of $21^{\text {st }}$ century. English is spoken at a useful level by some 1.75 billion people worldwide - that's one in every four. According to Mark Robinson Director and Exams British Council by 2020, two billion people will be using it - or learning to use it. And it is the economically active, leaders, business decision-makers, the young, the movers and shakers present and future who are learning and speaking English (British Council 2017).

In the Malaysian context, competency in communicating in English among local graduates has been the centre of contention with many commenting negatively. Although, Malaysia is ranked 14th out of 70 countries with high English proficiency in a survey by the EF English Proficiency Index, this surprised many who feel that the command of the language is wanting among students here (NST 2017).

The language grading issue is only the tip of the iceberg. Curriculum content, teaching methods and teachers' low language proficiency are all mentioned reasons for the decline of the language.

This paper presents a survey of English teaching in institution of higher learning in Malaysia. And explores current trends and challenges in English Learning/Teaching process in Malaysia.

\section{LITERATURE REVIEW}

There is a renewed interest to learn English to find common ground in the world of communicative effectiveness for business, trade, education, and tourism. And its importance is growing by the day.

Statistics from the British Council (2017) confirms the rationale to British way of delivering the language; traditional, effective and its reliable manner. And also due to the influence and consequence of the colonial rule, where it once prides on the statement "the sun never set on the British Empire".

Great Britain has proven its reliability and as a center of English language learning, through it many Universities. For instance, Oxford University that has been established 900 years ago, is one of the top universities in the world. British Council and many other language educational 
organizations have been established globally to give people the opportunity to learn English from native speakers through variety of cultural aspect, pronunciation and many other language specialties.

Even with these opportunities around, the data on English speaking level are disappointing in some regions. Based on the world largest ranking of countries by English skills 2016, the lowest percentage falls on Russia (40\%), Japan (43\%), Turkey (37\%) and some Asian countries like Mongolia (42.2\%), Kazakhstan (47.4\%), Cambodia (39.4\%), Laos (38.6\%). This disappointing statistics according to the psychologist and linguist Hendriks (2014) is due to following reasons:

1. Non-English speaking environment

2. Broken English speaking environment

3. Low percentage of cultural exchange with Native-English speaking countries.

\subsection{Challenges in learning English language}

Non- English speaking environment stands for the countries, where English is not a native language (Japan, China, Korea, Russia). Students find it difficult to practice the language outside the classroom, as the society communicates in their native local language. For example, in Japan, although students learn English for six years (starting the first year of junior high school), many of them still can't communicate in even basic English as the system is geared towards helping the students pass written university entrance exams by rote learning. Thus, the students spend hours memorizing complex English grammar rules but never spend anytime actually using English to communicate.

Broken-English speaking environment explains that cultural aspect of a certain country on English language speech, which creates the certain dialect (example: Nigerian broken English, Korean bamboo language, Liberian broken English, Italian American English, American ebonics language, Malaysia's Manglish, Singapore's Singlish, Tanglish in India). In the Kenya context, non-native teachers of English have problems with pronunciation. A teacher makes incorrect pronunciation of English words and ends up transferring the phonological rules from their first language into their English speech or comes up with own pronunciations of English words borrowed from their first language (Melchers and Shaw, 2003, cited in Margaret, 2013). 
Low percentage of the cultural exchange, majority of people from Third World countries find it difficult to travel and practice English and explore the culture of England due to economic reasons, and government programs usually can't provide enough slots for all students, who desire to speak good English. However, this trend is changing due to global connectivity brought about by budget airlines.

Demotivation - the act or an instance of motivating, or providing with a reason to act in a certain way (Dictionary.com, 2017). Demotivation among students is a common issue that affects the learning process and learning performance.

John \& Ehow (2011), view the problem of learning English language to a variety of reasons; school resources, class size, quality of teachers, and attendance of learners. Murray \& Christenson (2010), reasoned that many students think English as a mere academic subject and do not view its significance beyond classroom. Hutchinson \& Waters (1991) and Susanna (2007), pointed out a mismatch between theory and practice as a likely reason. Students' conceptual (or cognitive capacities) and the learners' English proficiency level often cause issue of match between students' learning style and teachers' teaching approach i.e. English course does not relate to the students' needs and interests. Susanna (2007), also claimed that weak students usually have poor strategies and give up easily when they find a struggle. Normazidah, Koo, \& Hazita (2012) and Trawiński (2005), identified factors that impacted the EFL learners:

- English is regarded as a difficult subject to learn.

- Learners' learning depends on the English teachers as authorities.

- There is a lack of support to use English in the home environment and the community.

- Learners have insufficient or lacking of exposure to the language, as there is a limited opportunity to use English outside the classrooms.

- Students have a limitation of vocabulary proficiency, as well as English reading materials are not always available.

- Learners have an unwillingness and lack of motivation to learn English as they do not see the immediate need to use the language.

- Lack of motivation for learning or the negative attitude towards the target language. 
There's nothing worse than going into a class full of people who don't really want to be there. ESL/EFL teacher most of them have the chance to work with a variety of age groups. Adults are usually in the classroom because they have made the choice to be there and in most cases they have made a financial commitment towards their learning and they know exactly what they want to achieve by improving their language skills.

However, children and teenagers often haven't made their own decision to attend the English class and they are obliged either by their parents or school to do so. It is sometimes appropriate for teachers to take an active role in trying to improve the motivation levels of a group. A highly motivated group of students is generally a lot easier and more fun to teach. Most teachers have come across de-motivated students at some time in their careers and it's often worth addressing the problem when it is possible to recognize it before it escalates further. However, teachers should not feel personally responsible for a student's lack of motivation (Budden 2003). There are often many factors that contribute towards a lack of motivation and these should be taken into account. Such as poor classroom environment or students cultural background (John \& Ehow 2011).

These factors have a certain impact on English learning/teaching process. In schools, students do not pay much attention to English learning as a result the low proficiency and it shows its consequences only when students at the certain age have a desire to pursue the academic career in one of the English speaking countries, migrate to another country or rather travel. Lack of knowledge of English leads to low confidence level among students and creating awareness of its importance at an early age (Murphy \& Evangelto 2016) avoid disappointing consequences.

Apart from the general problem of LEP there are some micro level issues that are seen as important like family background, individual, environmental, aspirations and expectation (Khattab, 2014; Marjoribanks 2002). Ngok (2014) mentioned that students are being demotivated by teachers themselves. The way of delivering the knowledge, teaching approach that is used in the classroom is more likely old and not relevant anymore to be implemented for the group of young people in his research.

In the words of Temmerman, (2017), "Teacher feedback can have a huge influence on student learning. Teachers who provide what students perceive to be unfair feedback can destroy students' academic motivation. And it doesn't take long for a demotivating teacher to 
discourage student interest, confidence as well as effort in a subject. Demotivated students think "why bother?"

Even silence is not an option, studies in Canadian public school by Walker (2014) has stated that lack of appreciation and encouragement has affected a group of students, the survey shows learners prefer to be encouraged by at least a verbal lift up once in a while.

\subsection{English Teaching in Malaysia}

\section{a. $C E F R$}

An English Language Standards and Quality Council was set up to focus on the foundation and structural changes to help raise the standard of English in the country in 2013. A Roadmap was drawn for English Language Education Reform in Malaysia spanning 2015 to 2025 - completed in 2016 and approved for implementation in June of the same year - a joint initiative with Cambridge English and Ministry of Education's English Language Teaching Centre as the lead agency.

The focus of the road map is to shift Malaysia's English Language Education System towards the Common European Framework of Reference for Languages (CEFR) - an international standard that focuses on producing learners who can communicate and interact in any language, in this case, English. CEFR is expected to play a vital role in the reform process in Malaysia's English Language education system for the coming decade. Incidentally, CEFR as the framework of reference is also an element in the Malaysia Education Blueprint aim to boost the level of education in the country.

CEFR for languages was developed by the Council of Europe more than 20 years before being officially launched during the European Year of Languages in 2001. CEFR has grown in popularity both in Europe and across the world. Hence, Malaysia aligning its English language teaching with CEFR is not surprising.

\subsection{British Curriculum and Teaching Approach Failure}

Malaysia is a multinational country with a government language Bahasa Malaysia and English (British) based on historical background. In Malaysia, it has become trendy to invest in knowledge especially English language. With support of the Malaysian Government and 
the approval of Ministry of Education, British English oriented language training organizations have been established.

However, it must be noted that although education ministry in Malaysia has conducted various programs to improve the standard of proficiency in English teaching, many of these initiative failed. For example, the decision made in 2003 by the government of the day to teach Science and Mathematics in English (the project known as PPSMI) was so hurriedly done with the result that there was insufficient time to plan and prepare for the change especially the teacher retraining aspects and was aborted. In a latest campaign to address staff skills, 70,000 teachers of English were required to pass the Cambridge Placement Test by 2015, or be moved to other roles (Ministry of Education Malaysia 2013).

However, many teachers had underperformed in this test, and what remedial measures taken is not clearly defined till now except for some politically motivated comments of concerned authority. At the same period, it was also announced that Malaysia has committed itself to ensuring that every child will be proficient in Bahasa Malaysia and English by 2025. Yet, a paper view; whether it works at the physical leave cannot be ascertained as no constructive debate untaken with concerned stakeholders till now.

And yet to broaden the English language gap, between the have and have nots, the government plans to include foreign branch campuses and public private partnerships. The British boarding school Epsom College opened a campus earlier this year, as well as a fiveyear $70 \%$ income tax exemption for new international schools. The government aims to make Malaysia a high income nation by 2020 and has prioritised education as a "key enabler for all National Key Economic Areas". Entry points include scaling up international schools and championing the country's international school brand. There are currently 128 Englishmedium international schools in Malaysia teaching a total of 53,366 students, according to data from the UK-based International School Consultancy Group (ISC 2017).

\subsection{English Teaching in Malaysia Higher Institutions}

Malaysia has overall 83 higher educational organizations which offer English Language courses, Academic English, Business English, preparation for IELTS and many more. These educational organizations can be divided as government and private sectors supporting British or American educational program. International schools in majority support IGCSE British program due to it stability, reliability and effectiveness, besides the colonial influence. 


\begin{tabular}{|c|c|c|}
\hline $\begin{array}{l}\text { Public educational institutions providing } \\
\text { English Language Course in Malaysia }\end{array}$ & $\begin{array}{l}\text { Private educational institutions providing } \\
\text { English Language Course in Malaysia }\end{array}$ & $\begin{array}{c}\text { English Language centers focusing on British } \\
\text { Curriculum in Malaysia }\end{array}$ \\
\hline $\begin{array}{ll}\text { - } & \text { Universiti Malaya (UM) } \\
\text { - } & \text { Universiti Sains Malaysia (USM) } \\
\text { - } & \text { Universiti Kebangsaan Malaysia (UKM) } \\
\text { - } & \text { Universiti Putra Malaysia (UPM) } \\
\text { - } & \text { Universiti Teknologi Malaysia (UTM) } \\
\text { - } & \text { Universiti Teknologi MARA (UiTM) } \\
\text { - } & \text { Universiti Islam Antarabangsa Malaysia } \\
\text { - } & \text { Universiti Utara Malaysia (UUM) } \\
\text { - } & \text { Universiti Pendidikan Sultan Idris (UPSI) } \\
\text { - } & \text { Universiti Teknikal Malaysia Melaka } \\
& \text { (UTeM) } \\
\text { - } & \text { Universiti Malaysia Perlis (UniMAP) } \\
\text { - } & \text { Universiti Sultan Zainal Abidin (UniSZA) } \\
\text { - } & \text { Universiti Pertahanan Nasional Malaysia, } \\
& \text { (UPNM) }\end{array}$ & 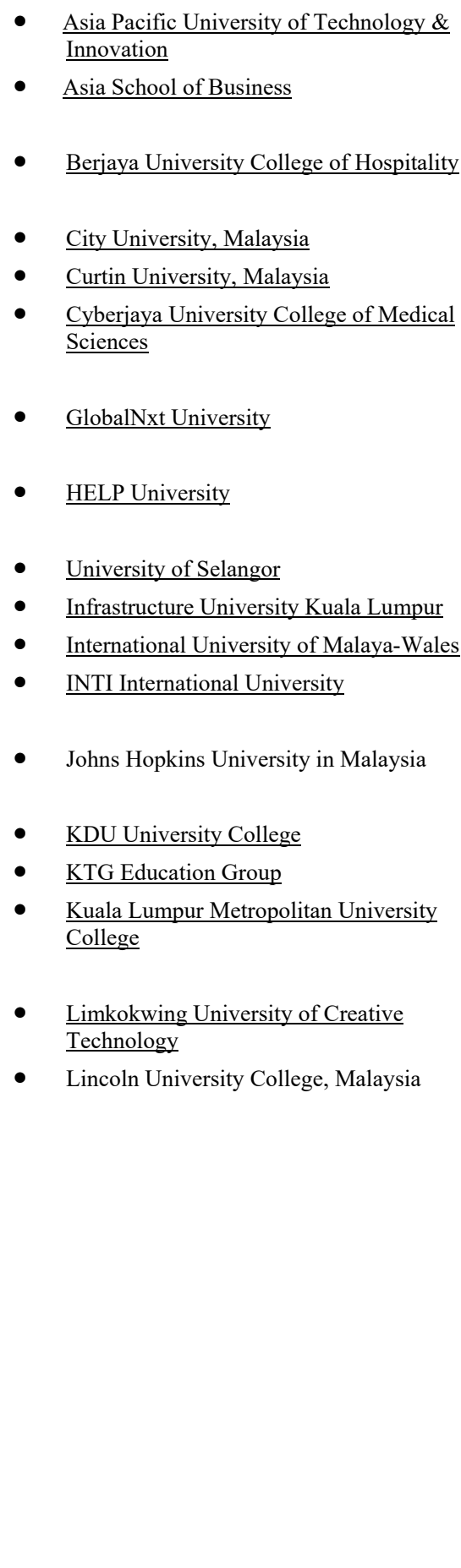 & 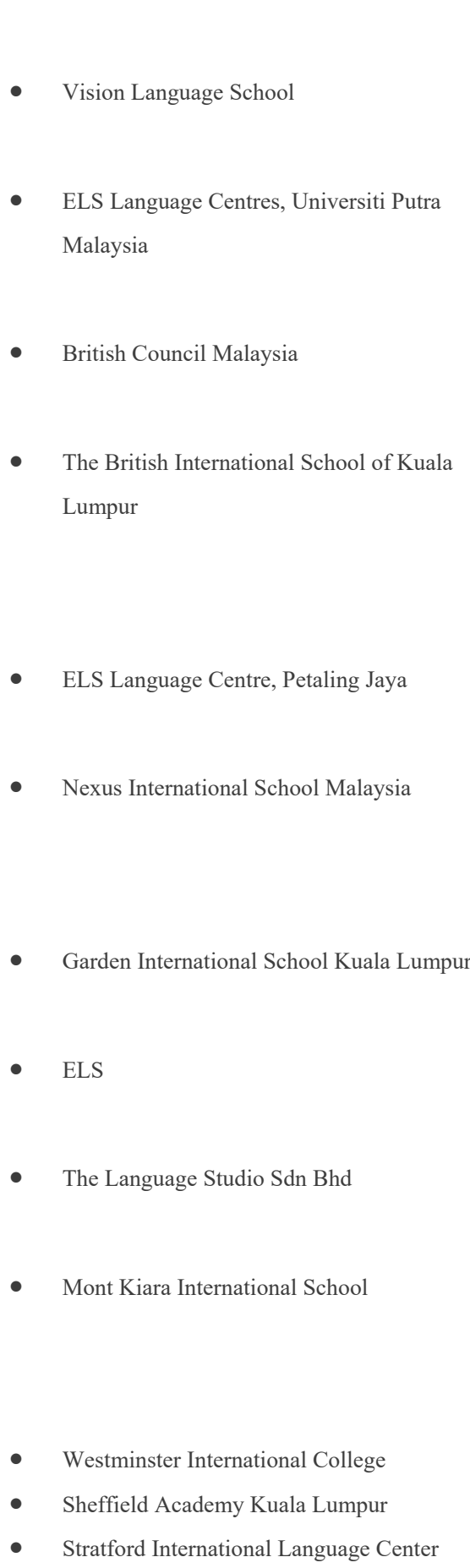 \\
\hline
\end{tabular}


The focus of public and private institutions is to run the English course to support their academic programs that are conducted in English.

\subsection{Public Institution of Higher Learning providing English Program}

Overall in Malaysia there are about 13 academic institutions of higher education providing English Language course. Based on the curriculum and main requirements for students to possess general/basic level of English equivalent to Elementary Level. Public universities follow Cambridge English syllabus as it standardized at university level; University Malaya, Universiti Sains Malaysia, University Sultan Zainbal Abidin, Infrastructure University Kuala Lumpur, Universiti Putra Malaysia to name a few. In tertiary English for non-English majors, it varies with Universities (about 9 credit), no standardized textbook (free selection). The focus is on academic writing and professional communication skills.

Malaysia do not administer a nation-wide university entrance examination, however, a prerequisite English test on proficiency named Malaysia University English Test (MUET) is administered for university admission, (especially for public universities, minimum grade is required, and it varies with majors selected).

Universities set different target band scores for different courses. The universities set the minimal requirement of a Band 3 in MUET, while students who want to study Medicine, Law, TESL, English Linguistics, and English Literature are required to obtain at least a Band 4. MUET is also compulsory for graduating from a local university. 


\begin{tabular}{|c|c|c|c|c|c|}
\hline $\begin{array}{l}\text { Aggregated } \\
\text { score }\end{array}$ & Band & User & Communicative ability & Comprehension & Task performance \\
\hline $260-300$ & 6 & $\begin{array}{l}\text { Highly proficient } \\
\text { user }\end{array}$ & $\begin{array}{l}\text { Very fluent, highly appropriate use of language; hardly } \\
\text { any grammatical error }\end{array}$ & $\begin{array}{l}\text { Very good understanding of language } \\
\text { and context }\end{array}$ & $\begin{array}{l}\text { Very high ability to function in } \\
\text { the language }\end{array}$ \\
\hline $220-259$ & 5 & Proficient user & $\begin{array}{l}\text { Fluent; appropriate use of language; few grammatical } \\
\text { errors }\end{array}$ & $\begin{array}{l}\text { Good understanding of language and } \\
\text { context }\end{array}$ & $\begin{array}{l}\text { High ability to function in the } \\
\text { language }\end{array}$ \\
\hline $180-219$ & 4 & Satisfactory user & $\begin{array}{l}\text { Generally fluent, generally appropriate use of } \\
\text { language, some grammatical errors }\end{array}$ & $\begin{array}{l}\text { Satisfactory understanding of } \\
\text { language and context }\end{array}$ & $\begin{array}{l}\text { Satisfactory ability to function in } \\
\text { the language }\end{array}$ \\
\hline $140-179$ & 3 & Modest user & $\begin{array}{l}\text { Fairly nuent, lairly appropriate use of language; many } \\
\text { grammatical errors }\end{array}$ & $\begin{array}{l}\text { Fair understanding of language and } \\
\text { context }\end{array}$ & $\begin{array}{l}\text { Fair ability to function in the } \\
\text { language }\end{array}$ \\
\hline $100-139$ & 2 & Limited user & $\begin{array}{l}\text { Not fluent, inappropriate use of language; very frequent } \\
\text { grammatical errors }\end{array}$ & $\begin{array}{l}\text { Limited understanding of language } \\
\text { and context }\end{array}$ & $\begin{array}{l}\text { Limited ability to function in the } \\
\text { language }\end{array}$ \\
\hline Below 100 & 1 & Very limited user & Hardly able to use the language & $\begin{array}{l}\text { Very limited understanding of } \\
\text { language and context }\end{array}$ & $\begin{array}{l}\text { Very limited ability to function in } \\
\text { the language }\end{array}$ \\
\hline
\end{tabular}

Source: Malaysian Examinations Council

\subsection{Private Institution of Higher Learning providing English Program}

Private sectors expand the spectrum of learning English courses and provide degrees and diplomas specializing in English:

- Cambridge Certification Programs

- Intensive English Programs

- Academic English Programs

- Business \& Professional English

- Bachelor of Arts (English Language Studies)

- Bachelor of TESL (Teaching of English as a Second Language)

University of Nottingham (off score campus), SEGI University UCSI University for instance, provide degrees in TESOL and focus on English oriented programs. One of the compulsory requirements from private educational institutions for abituriants is to provide IELTS certificate with minimum 6.5 score in order to prove that subjects, which are held in English will be well understood by the student. IELTS examination measures the English language based on 4 skills: Listening, Reading, Writing, Speaking. It has become a popular trend to request for this examination certificate to support the academic profile of a student. In the event of failing this examination, students would take a one year English language course in university, after completion they may continue oriental education. For the convenience purposes universities in 
Malaysia (Taylors University) offer internal English examination to evaluate the level of the abituriants, in the occasion of failure, the same procedures take place. Considering the fact that English language maybe a barrier to pursue educational development, the best solution for students to attend courses in Language centers and authorized academies.

\subsection{Stand-alone Institution of Higher Learning providing English Program}

There are institutions that are fully focused on training the language skills of the students. Nowadays English language educational centers are mushrooming around Malaysia offering English program at different level and time period.

Some examples of English programs conducted are:

Preparatory Courses:

- IELTS Preparatory Course

Short Courses (6 months to 1 year):

- Cambridge Certification Programs

- Intensive English Programs

- Academic English Programs

- Business \& Professional English

The top ten English Language education centers based on the tallypress.com website:

1. The Language House

2. British Council

3. ELS Malaysia

4. Stratford International Language Center

5. English Language Company

6. Stratford Language Center

7. Wall Street English

8. Erican Language Center

9. Standard Language Center

10. IMEC

However, there is no criteria presented for the set of these particular institutions. 
In terms of importance of the aim of the international teaching standards according to such educational centers is to provide the knowledge in the interaction way, however different educational groups have different curriculum and some support mixed framework of combination of American and British curriculum.

The pioneer Educational organization, which is focused on British curriculum and educational British educational framework, is British Council. However, there are other institutions that are also competing in this niche and it is a good destination of English Language learning. Classes in such educational groups are pretty intense, as English classes occupy the whole day approximately 10 am - 5 pm. For 1-hour session, the student spends around 3 hours' revision afterwards; British academic program is based on memorizing and research. The most important stage is passing examination IELTS. These two certificates prove the proficiency of English worldwide it is a ticket to future job opportunities and academic career.

Taking IELTS opens doors. It can help live, study and work around the world. More than 9,000 organizations worldwide accept IELTS, including government, academic and employment institutions. In fact, IELTS is the only English language test accepted for immigration purposes by all countries that require one.

The IELTS test is designed to help people use English in their new life abroad. In less than three hours, it will assess all of English skills: listening, reading, writing and speaking.

Of course to score well, student required to put maximum effort towards studies. And international language center provides all kinds of facilities and resources to motivate students.

Eberly Center for Teaching Excellence \& Educational Innovation, Carnegie Mellon University 2015 suggests the common reasons of students demotivation:

- Students do not believe that their efforts will improve their performance.

- Students are demotivated by structure and allocation rewards.

- Students do not perceive the classroom climate as supportive.

- Students have other priorities that compete for their time attention. 
- Students in schools are losing their motivation to learn English and are becoming more demotivated as time.

One of the major issues among English Learners in Malaysia is the environment outside the regular class. Malaysia is multinational country with the government language Bahasa Malaysia with the mixture of Tamil and Chinese Mandarin or Cantonese languages. People on the streets prefer to communicate in the "comfortable language" government organizations require communication in $\mathrm{BM}$, some families embrace the native language (Mandarin, Cantonese, Tamil, Hindu). Low percent falls on the pure English language practice and communication. However, Malaysia welcomes expats every year, so English learners can find a friend from English speaking countries to improve the pronunciation and expand vocabulary. It becomes challenging for many learners to practice proper English. For this reason, Language Academies and Schools provide maximum activities outside curriculum to support learners to improve English daily. What comes to Higher Institutions, which are closely under the management of Ministry of Education, the system is quite inflexible. One reason for the lack of greater change lies in the widely acknowledged fact that change in any type of organization, educational institutions included, takes time and requires great amounts of education, effort, persistence, and skill. However, the researchers are interested whether a Teaching Paradigm shift in English teaching has taken place due to weak grip of the language?

\section{METHODOLOGY}

The participants in this study involved final year undergraduates, newly graduated and newly employed graduates in and around Klang Valley, the hub of academic and employment activities. The participants were initially identified by current students of Binary University who volunteered to undertake enumeration aspects. Snowballing techniques was used to identify other participants and the final tally was 100 for this exploratory study. 


\section{Survey Results}

\begin{tabular}{|c|c|}
\hline Non-habitual speakers of English & Habitual speakers of English \\
\hline $70 \%$ & $30 \%$ \\
\hline Mix local language in English & Think in native language and translate to English \\
\hline Sometimes $43 \%$ & Yes $17 \%$ \\
\hline All the times $57 \%$ & No $83 \%$ \\
\hline \multicolumn{2}{|c|}{ Hesitated to speak English: } \\
\hline Worried making grammar errors & $25 \%$ \\
\hline Felt embarrassed at low language pro & $10 \%$ \\
\hline Received negative physical response & \\
\hline & \\
\hline Sustain and critically analyze and rebuttal in English & \\
\hline Yes $80 \%$ & If yes: Converse in pure English \\
\hline \multicolumn{2}{|c|}{} \\
\hline No $20 \%$ & Yes $45 \%$ \\
\hline
\end{tabular}

\section{Discussion}

Based on survey findings, the command of English language is an issue. The obstacles are mostly faced by English learners in grammar and construction of the sentences. Students are not in a pure English spoken environment, so the realization of the wrong pronunciation is not there and it's a common issue when students mix of English with a local dialect. The grammar foundation is not strong, and vocabulary baggage is insufficient. English Learners have the wrong perception of importance of the language, as well as they could be understood it is enough to keep moving in secondary or high school environment. The Low English Proficiency will arise when students fail MUET or IELTS or any other equivalent examination while applying to Higher Institution of Learning. The types of current exposure to University English program is insufficient to allow a person to speak English fluently. These are the consequences of earlier exposure to English in Primary/Secondary schools in Malaysia.

Critical view. There is a gap between Public and Private Secondary/High school standards of the English language subject. Government schools provide general knowledge of English and Private schools follow European and Singaporean syllabus. But due to the low proficiency among facilitators both (Government and Private Secondary educational institutions) the 
level of English preparation is below satisfactory. However, Government Policy (European Educational Framework) expected to bare through and improve the situation for the better. The brand new approach of teaching English in Malaysia based on Cambridge English Framework could expectedly show its results in the next 10 years.

\subsection{Teaching Paradigm Shifting}

One of the positive elements of nature is a change, with the process of globalization the educational environment in the classroom has dramatically changed and it can be observed in the classrooms nowadays. Malaysia as many other countries follow the trend. Before focusing on the trends in teaching English, we can take a look at the difference between traditional teaching and modern teaching paradigms. For example, Larsen-Freeman (1998) challenges conventional views and offers ways to teach grammar consistent with contemporary views with the focus on form within a meaning-based or communicative approach and Genesee \& Upshur (1996) discussed about tools in the use of classroom-based assessment for improving both teaching and learning, consistent with view expressed also by Tudor (1996) who discussed in length the role of Teacher in learner-centred classroom.

Traditional Teaching Paradigm:

1. Focus on language as a subject

2. Teachers-centered

3. Individual learning

4. Limited assessment (test, multiple choices) 4. Expanded assessment (essay, coursework)

5. Focus on the rules

6. Focus on memorizing

7. Emphasis on the result

8. Usage of traditional tools (board, chuckles) 8. Implementation of technology

Modern Teaching Paradigm:

1. Focus on the language as a culture

2. Learners-centered

3. Cooperative learning

5. Focus on the fluency and understanding

6. Focus on integrativeness

7. Emphasis on the process

With the implementation of the modern teaching ways the atmosphere in the classroom has become friendlier and more comfortable for learners to make mistakes and work on it. As well students tend to understand the origin of foreign words based on the cultural aspect of the English speaking countries, especially England, as it became traditional to represent 
English language in a context of England. However, students may request the variety in English, for example American English, which has become trendy. Assessments in the classroom have taken an integrative form, whereby a student can write an essay or make a research on the certain topic. The process of learning the subject became more exciting and interesting and the positive result is a complement to the great work that has been done. The attention to the English facilitators has become a serious issue. As it is important for the teacher not only to know the subject perfectly but to know how to interact with students and create a positive atmosphere in the classroom.

\subsection{Proficiency and Training of Facilitators of English learning (CELTA/DELTA)}

CELTA stands for Certificate in Teaching English to Speakers of Other Languages is an initial teacher training qualification for teaching English as a second or foreign language (ESL and EFL).

It is provided by Cambridge English Language Assessment through authorized Cambridge English Teaching Qualification centres. The course enables candidates to:

- Acquire essential subject knowledge and familiarity with the principles of effective teaching

- Acquire a range of practical skills for teaching English to adult learners

- Demonstrate their ability to apply their learning in a real teaching context

Delta (Diploma in Teaching English to Speakers of Other Languages) is for teachers with at least one year's experience. It's suitable for teachers in any context, working with any age range - young learners, teenagers or adults.

The wave of the trend for CELTA and DELTA has covered the world in 2014 it was prestigious for teachers to hold this qualification, but in 2016/2017 it has become a number one requirement from employers, it is important for the teacher to possess any of these certificates in order to assure that teacher has an understanding of modern teaching paradigm and will need no training for delivering the classes in the correct manner. In Malaysia CELTA and DELTA can be granted only in British Council, which is number one authorized English teaching organization. 


\section{Conclusion}

This study aimed to explore/survey the English Language nature in Malaysia its challenges and trends. The observation has been done from three different angles. Public Private and Stand Alone institutions of higher learning. Survey has stated that British based curriculum in Malaysia is in demand due to the colonial influence and for its effectiveness and reliability. Furthermore, this article disclosed common trends in English learning field, the current challenges such as discouraging English speaking environment and low teaching proficiency. However, Malaysia is following towards improving the quality of teaching/learning routine progressively. Malaysian Government takes leaps to provide the positive opportunities for English learners. The important aspect is the shift Malaysia's English Language Education System towards the Common European Framework of Reference for Languages this contribution expectedly will impact the English learning in a positive way. This research carries the educational and practical significance and could be a startup platform for future researchers.

\section{Reference:}

1. Alderman, K. 2004. Motivation for Achievement: Possibilities for Teaching and Learning. Lawrence Erlbaum Associates

2. British Council, 2017. THE ENGLISH EFFECT The impact of English, what it's worth to the UK and why it matters to the world

3. https://www.britishcouncil.org/sites/default/files/english-effect-report-v2.pdf. Retrieved $8^{\text {th }}$ August 12, 2017

4. Budden j, 2003. Motivating Teenagers. Retrieved $8^{\text {th }}$ August 12, 2017 http;/www.teachingenglish.org.uk/think/articles/motivating-teenagers.

5. Crookes, G., and Schmidt, R.W. 1991. "Motivation: Reopening the Research Agenda." Language Learning 41:469-5 12.

6. Coleman, T. A. 1995. "Progress, Proficiency, and Motivation among British University Language Learners” (ED 383221).

7. Christensen, C. Horn, M. Johnson, C. 2010. Disrupting Class: How Disruptive Innovation Will Change the Way the World Learns 2ndedition McGraw--Hill

8. Current Trends and Issues in English Language ... - Asia TEFL. www.asiatefl.org/main/download_pdf.php? $\mathrm{i}=262 \& \mathrm{c}=1419312102$. Retrieved $8^{\text {th }}$ August 12,2017

9. CHARLE, A.\& Szabo, A. 2005. Learner Autonomy, A guide to developing learner responsibility. United Kingdom: Cambridge University Press

10. Carlo, M. 2012. Teaching English to Speakers of Other Languages. TESOL Journal, 6.

11. http://ejournal.ukm.my/gema/article/view/20. Retrieved $8^{\text {th }}$ August 12, 2017

12. Dornyei, Z. 1990. "Conceptualizing Motivation in Foreign Language Learning." Language Learning 40:45-78.

13. Dictionary.com, 2017. http://www.dictionary.com/browse/motivation. Assessed on $30^{\text {th }}$ August 2017. 
14. Genesee, F. and J. A. Upshur. 1996.Classroom-basedEvaluation in Second Language Education. New York: Cambridge University Press.

15. Hutchinson, T., and Waters, A. 1991. English for Specific Purposes. Cambridge University Press.

16. Hendriks, P. 2014. Asymmetries between Language Production and Comprehension. Studies in Theoretical Psycholinguistics, Vol. 42. Dordrecht: Springer

17. ISC, 2017. https://www.iscresearch.com/news/isc-news. Retrieved $8^{\text {th }}$ August 12, 2017

18. Jacobs, G.M. 1998. "Cooperative Learning or Just Grouping Students: The Difference Makes a Difference.", Learners and Language Learning. Anthology Series 39.

19. John, L., Ehow, C. 2011. Factors Affecting Quality of English Language Teaching and Learning. Retrieved from http://www.ehow.com/info_8040040_factors-englishlanguage-teaching-learning.html. Retrieved $8^{\text {th }}$ August $12,201 \overline{7}$

20. Jacobs, G.M., Crookal D. and R. Thiyagarajali. R. 1997. "The Evolution of Group Activities in ELT Course book." Singapore: SEAMEO-Regional Language Centre. Folio 4:2. 19-23.

21. Krashen, S. 1982. Principles and Practice in Second Language Acquisition. Pergamon Press

22. Krashen, S. 1993. The Power of Reading: Insights from the Research. Englewood, York: Prentice Hall.

23. Krashen, S. 1997. “The Comprehension Hypothesis: Recent Evidence.” English CO: Libraries Unlimited.

24. Kuhara-Kojima, K., and G. Hatano. 1991. "Contribution of Content Knowledge" Teachers' Journal 51. 17-29.

25. Kuhara-Kojima, K., and Hatano, G. 1991. Contribution of content knowledge and learning ability to the learning of facts. Journal of Educational Psychology,83, 253-263.

26. Kedzierski, M. 2016. "English as a medium of instruction in East Asia's higher education sector: a critical realist Cultural Political Economy analysis of underlying logics". Journal Comparative Education Volume 52, 2016

27. Khattab, N. (2014) How and when do educational aspirations, expectations and achievement align? Sociological Research Online, 17 (4), 7.

28. Larsen-Freeman, D. 1998. Teaching Grammar, https://www.uibk.ac.at/anglistik/staff/freeman/course-documents/tesfl_teaching_grammar.pdf

29. Malaysian Examinations Council, 2017. portal.mpm.edu.my/en/muet1

30. Ministry of Education Malaysia, 2017. www.moe.gov.my/index.php/en

31. Marjoribanks, K. (2002) Family background, individual and environmental influences on adolescents' aspirations, Educational Studies, 28, 33-46

32. McDonough, S.2007. Motivation in ELT. Oxford ELT Journal. (61/4): 369-371. http:/eltj.oxfordjournals.org/cgi/reprint/61/4/369? maxtoshow=\&HITS=10\&hits $=1$ 0\&RESULTFORMAT $=\&$ fulltext $=$ motivation\&searchid $=1 \&$ FIRSTINDEX $=0 \&$ resource type $=$ HWCI.T. Accessed $7^{\text {th }}$ July7, 2017).

33. Murphy Victoria A. and Evangelou, Maria. 2016. Editors of ... Early Childhood Education in English for Speakers of Other Languages. https://www.teachingenglish.org.uk/sites/teacheng/files/F240\%20Early\%20Childhood\% 20Education\%20inners\%20FINAL\%20web.pdf. Assessed on $24^{\text {th }}$ August 2017

34. Margaret Gatavi Njeru1, 2013. Dialect and the Learning of English as a Second Language in Kenya, English Linguistics Research Vol. 2, No. 1; 2013. Online Published: May 28, 2013: http://dx.doi.org/10.5430/elr.v2n1p128

35. Murray, D. E and Christenson, M. A. 2010. What English Teachers Need to Know 
36. http://perpus.stkipkusumanegara.ac.id/file_digital/Buku\%20Digital\%2072.pdf. Retrieved $8^{\text {th }}$ August 12, 2017

37. Normazidah, C. M., Koo, Y. L., and Hazita, A. 2012. Exploring English language learning and teaching in Malaysia. GEMA Online ${ }^{\mathrm{TM}}$ Journal of Language Studies, 12(1), 35-55.

38. NST, 2017. Thursday, 31 August 2017. https://www.nst.com.my

39. Susanna, A. 2007. The weak language learner: a study of ways of taking weak language learners into consideration in class. Sweden: Vaxjo University, School of Humanities English, GIX115.

40. Temmerman, N. 2017. Unfair teacher feedback means demotivated students, University World News, 17 March 2017 Issue No:451

41. Tudor, I. (1996a). Teacher roles in the learner-centred classroom. In T. Hedge \& N. Whitney (Eds.), Power, pedagogy and practice (pp. 271-282). Oxford: Oxford University Press

42. Trawiński, M. 2005. An Outline of Second Language Acquisition Theories. Wydawnictwo Naukowe Akademii Pedagogicznej. 